\title{
Kinetic Study on the Effect of Substrate and Micronutrient Inhibition during Anaerobic Fermentation of Biohydrogen
}

\author{
Nurul Sakinah Engliman', Ainul Husna Abdul Aziz², Mariatul Fadzillah Mansor ${ }^{3}$, Peer Mohamed Abdul', \\ Jamaliah Md Jahim ${ }^{5}$, Nur Syakina Jamali ${ }^{6}$ \\ ${ }^{1,2,3}$ Department of Biochemical-Biotechnology Engineering - International Islamic University Malaysia (IIUM), Address: Jalan \\ Gombak, P.O. Box 10,50728, Gombak, Kuala Lumpur, Malaysia \\ ${ }^{4,5}$ Research Centre for Sustainable Process Technology (CESPRO), Faculty of Engineering and Built Environment, Universiti \\ Kebangsaan Malaysia (UKM), Bangi, 436000, UKM, Selangor, Malaysia \\ ${ }^{6}$ Department of Chemical and Environmental Engineering, Faculty of Engineering, Universiti Putra Malaysia, Serdang 43400, \\ Malaysia
}

\begin{abstract}
There are several factors that influence the production of biohydrogen by dark fermentation including inoculum seeds, type and concentration of substrate, $\mathrm{pH}$, temperature, presence of micronutrient and reactor configuration. Previous research has proven that the concentration of substrate and the presence of micronutrient will influence the yield and productivity of biohydrogen production. However, improvement of yield and productivity of the process can only be achieved once the system is under the optimum amount of substrate and micronutrient. Therefore, the best way to determine the effect of substrate concentration and presence of micronutrient is through kinetic study that was done using Monod model along with Andrews model. Besides that, the substrate inhibition effect also will be evaluated to determine the maximum substrate that needs to be supplied for maximum hydrogen production, and thus supplied the information for economic feasibility for fermentation process. In the meantime, the inhibition effect of adding the iron nanoparticles also had been evaluated in order to understand the interaction effect between iron nanoparticles and bacteria in term of catabolism reaction. It was found that increasing the substrate concentration more than $10 \mathrm{~g} / \mathrm{l}$ will cause the inhibition to the system, in which it will slow down the reaction process and reduced the production of hydrogen. While the presence of iron NPs more than its optimum value $(200 \mathrm{mg} / \mathrm{l})$ will inhibit the bacterial growth and hence, affect the hydrogen production. For both cases, when the inhibition occurred at the respective concentration, it was found that the metabolic pathway was shifted to produce more hydrogen-consuming metabolite such as propionate acid, and thus, dropped the hydrogen production.
\end{abstract}

KEYWORDS: Anaerobic Fermentation, Biogas, Inhibition, Kinetic Study

\section{INTRODUCTION}

Biohydrogen production involves mixed community of bacteria that bring about an ecological pattern that is different from pure culture in which the growth rate and microbial activity was affected by diurnal variation of substrate, $\mathrm{pH}$, DO and temperature [1]. In typical fermentation process, substrate concentration and addition of micronutrients are among the crucial factors that will affect the productivity and yield of the process. Ginkel and his co-worker has demonstrated that the presence of the appropriate concentration of substrate during hydrogen fermentation could increase the ability of the hydrogen-producing bacteria to produce maximum amount of hydrogen [2]. However, the optimal amount of substrate and micronutrients need to be determined or otherwise the presence of excess amount of it will inhibit the process [3]. The presence of optimal substrate concentration and micronutrients are able to improve the metabolic reaction of microbes which have a relationship with microbial growth.

In order to understand the substrate utilization by the microorganism during the fermentation process, kinetic model such as Monod equation is commonly used to describe the correlation of microbial growth with substrate intake [4]. Through Monod equation (Equation 1), one can determine the growth-limiting substrate that may affect the bacterial growth. Monod equation is the adaptation from Michaelis-menten kinetic model that had been used in enzymatic reaction, but when applied to cellular system, it is known as Monod equation.

$$
\mu=\frac{\mu_{\max } S}{K S+S}
$$
(Equation 1) 


\section{International Journal of Current Science Research and Review}

ISSN: 2581-8341

Volume 05 Issue 01 January 2022

DOI: 10.47191/ijcsrr/V5-i1-03, Impact Factor: 5.825

where $\mu$ is a specific growth rate $\left(\mathrm{h}^{-1}\right), \mu_{\max }$ is the maximum growth rate $\left(\mathrm{h}^{-1}\right), \mathrm{S}$ is the substrate concentration $(\mathrm{g} / \mathrm{l})$, and Ks is the half saturation coefficient $(\mathrm{g} / \mathrm{l})$.

Later, in 1905, Blackman had discovered the relationship between bacterial growth and substrate concentration in which he found that, at high substrate concentration, bacterial growth rate as well as substrate uptake rate are both independent of the substrate concentration that probably due to intracellular factors that limited for metabolic reaction under this condition [4]. Figure 1 shows that the increasing of substrate concentration will increase the specific growth rate, $\mu$ and finally reaches an asymptotic value $\mu_{\text {max }}$.

$$
\begin{array}{ll}
\mu=\mu_{\max } \mathrm{S} / \mathrm{Ks} & \text { when } \mathrm{S}<\mathrm{Ks} \\
\mu=\mu_{\max } & \text { when } \mathrm{S} \geq \mathrm{Ks}
\end{array}
$$

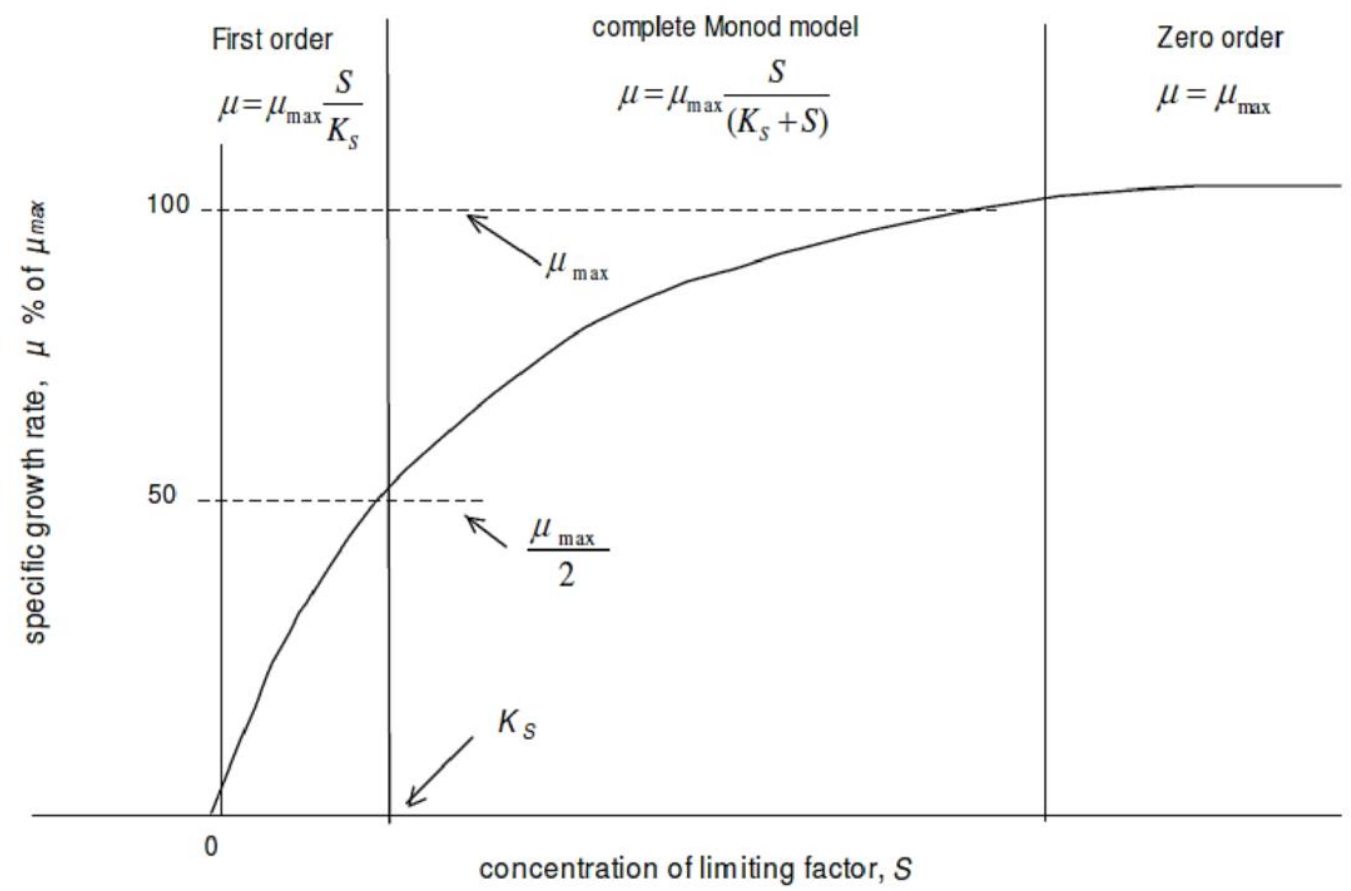

Figure 1: Relationship between substrate concentration, $S$ and the specific growth rate under the ideal condition for Monod equation.

However, increasing the substrate concentration will inhibit a fermentative hydrogen production and thus, Equation 1 is no longer applicable. Modified Monod equation had been introduced by Andrew model (Equation 2), where Ki is inhibition coefficient [5].

$$
\mu=\frac{\mu_{\max } S}{\left(K S+S+\left(\frac{S^{2}}{K i}\right)\right.} \quad \text { (Equation 2) }
$$

Several studies had used Andrew model to describe the substrate inhibition to the fermentative hydrogen production [6]-[9]. So far, the Monod equation as well as modified Monod such as Andrew equation is the best model that describe the effects of substrate concentration on the rates of substrate degradation, bacterial growth, and hydrogen production.

Besides the kinetic model such as Monod that describes the substrate utilization which affects the bacterial growth, the inhibitory effects of salts or trace elements on bacterial growth as well as hydrogen production also can be evaluate through kinetic model by using Han-Levenspiel model [10]. This model described that when the inhibitor concentration increases to $\mathrm{C}_{\text {crit, }}$, the specific growth rate, $\mu$ will decreases from $\mu_{\max }$ to zero. It is believed that the presence of excess number of salts or trace elements may affect the intracellular metabolism of the bacteria, which is able to inhibit the enzyme reaction involved in hydrogen production [11]. To the best of our knowledge, the effect of trace elements such as addition of iron nanoparticles has not yet been addressed using this model 


\section{International Journal of Current Science Research and Review}

ISSN: 2581-8341

Volume 05 Issue 01 January 2022

DOI: 10.47191/ijcsrr/V5-i1-03, Impact Factor: 5.825

IJCSRR@ 2022

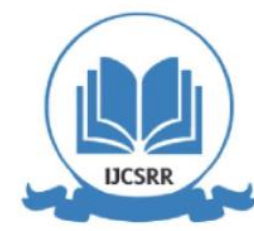

Www.ijcsrr.org

on hydrogen production. It is because the presence of iron nanoparticles will involve the hydrogenase enzyme that will make the model more complicated due to intracellular factors that is limited to be monitored, thus, more research on these aspects is needed.

Therefore, this research is aimed to determine the effect of substrate concentration on bacterial growth using the kinetic model. Besides that, the substrate inhibition effect also will be evaluated to determine the maximum substrate that need to be supplied for maximum hydrogen production, and thus supplied the information for economic feasibility for fermentation process. In the meantime, the inhibition effect of adding the iron nanoparticles is also evaluated in order to understand the interaction effect between iron nanoparticles and bacteria in term of catabolism reaction. Thus, this research will examine the optimization and kinetic modeling of hydrogen production using mixed culture bacteria from palm oil mill effluent sludge in thermophilic condition by employing the substrate utilization model and inhibition model due to presence of iron nanoparticles.

\section{METHODOLOGY}

\section{A. Seed Sludge}

The sludge was taken from palm oil mill effluents (POME) and was used as the seed sludge in this experiment. The seed sludge was acclimatized for duration of one month in $1 \mathrm{~L}$ Schott Durant bottle before further progress into different glucose concentration in batch mode process to make sure the seed was in stable condition to produce biohydrogen. In addition, the seed sludge was feed for every two days with initial $\mathrm{pH}$ adjusted to $5.5 \mathrm{using} 1 \mathrm{M}$ of hydrochloric acid or sodium hydroxide.

\section{B. Experimental Procedure}

The experiment was conducted by using $300 \mathrm{ml}$ Schott Durant bottle. 1 liter of nutrient solution for the seed consisted peptone of $3 \mathrm{~g}$, yeast extract of $3 \mathrm{~g}, \mathrm{NaCl}$ of $1 \mathrm{~g}, \mathrm{C}_{3} \mathrm{H}_{3} \mathrm{NaO}_{2}$ of $1 \mathrm{~g}$ and L-cysteine of $0.5 \mathrm{~g}$. All of these compositions were prepared on basis of 1 liter. $15 \mathrm{ml}$ of acclimatized seed sludge, $170 \mathrm{ml}$ of nutrient solutions and glucose ranges of 0 to $50 \mathrm{~g} / \mathrm{l}$ were added into the bottle. The calculation of each the glucose concentrations were made on basis of $200 \mathrm{ml}$ of working volume. Then, the bottle was filled up to $200 \mathrm{ml}$ working volume with $100 \mathrm{ml}$ headspace. The initial $\mathrm{pH}$ of 5.5 for every bottle from 0 to $50 \mathrm{~g} / \mathrm{l}$ was adjusted by $1 \mathrm{M}$ of hydrochloric acid or sodium hydroxide. The batch mode test were conducted at $55^{\circ} \mathrm{C}$ [12].

\section{Analytical methods}

The collection of the biohydrogen produced were taken using water displacement method. The fraction of hyrdrogen in the biogas was determined by using gas chromatograph. The carrying gas of helium is used at the flow rate of $12 \mathrm{ml} / \mathrm{min}$. The gas production data was reported and standardized to the standard temperature of $0{ }^{\circ} \mathrm{C}$ and pressure of $760 \mathrm{~mm} \mathrm{Hg}$. The metabolites of soluble that presented inside the mixed culture were also analysed by a high performance liquid chromatography (HPLC). The $\mathrm{pH}$ level was measured by using pH probes. The volatile suspended solid (VSS) of the seed sludge was determined using the standard method application. According to the standard method, VSS are those solids lost on ignition (heating to $550{ }^{\circ} \mathrm{C}$ ). They represent a rough approximation of organic matter that presents in the fraction of the mixed culture bacteria.

\section{Kinetic analysis on the effect of substrate and micronutrients concentration on bacterial growth and biohydrogen production}

In order to analyse the effect of substrates concentration, the experimental data were analyzed using MATLAB software. The modeling of rate equations for biomass $(\mathrm{X})$, hydrogen production $(\mathrm{P})$ and glucose $(\mathrm{S})$ were used to explain the fermentation process. The unstructured models which was widely used to describe the microbial cell growth was the Monod model. Meanwhile to estimate the amount of optimum substrate for maximum growth rate, Monod equation was used (Equation 1). This kinetic model was used to describe the interaction of the growth of microbial with the intake of substrate [10]. Generally, Monod model was implemented to describe the substrate concentrations effects on the rates of degradation of substrates, HPB growth, and the production of hydrogen [11]. As we know that, glucose (substrate that commonly used for anaerobic fermentative of biohydrogen) always act as limiting substrate during the bacterial growth. The utilization of this substrate was commonly determined using monod equation..

\section{RESULT AND DISCUSSION}

\section{A. Effect of substrate concentration on biohydrogen production}

The effect of substrate concentration can be explained in Figure 2, in which for the biohydrogen production in batch experiments, the biogas produced increased with increasing glucose concentration, but it decreased when the glucose concentration was more 


\section{International Journal of Current Science Research and Review}

ISSN: 2581-8341

Volume 05 Issue 01 January 2022

DOI: 10.47191/ijcsrr/V5-i1-03, Impact Factor: 5.825

IJCSRR@ 2022

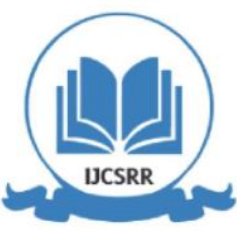

www.ijcsrr.org

than $15 \mathrm{~g} / \mathrm{l}$. The maximum hydrogen production was achieved when glucose concentration was $15 \mathrm{~g} / \mathrm{l}$, which is $277 \mathrm{ml}$ respectively. This showed that when the substrate concentration is in an appropriate range, it is able to increase the biohydrogen production, however, when the substrate concentration is more than the optimum range, it will cause the biohydrogen production to drop [13].

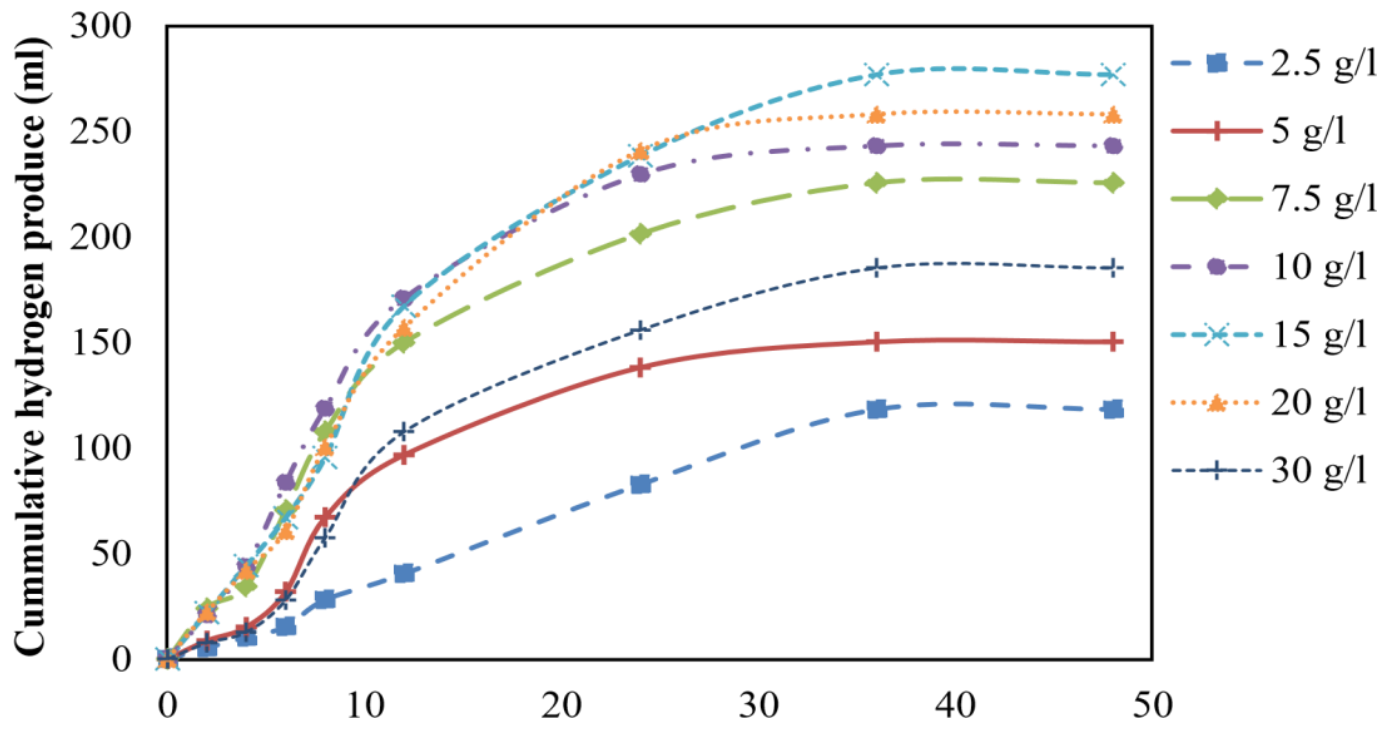

Fermentation time (hrs)

Figure 2: Cumulative hydrogen production from mixed culture using various concentration of glucose.

Meanwhile, the substrate utilization also shows the increasing trend with the increasing of glucose concentration (Figure 3). After it reached the optimum value, the percentage of substrate utilization decreases. This trend proved that at low level of substrate concentration, bacteria able to utilize or degrade the substrate without any obstacles, but when the substrate concentration increases more than the limit of the bacterial cells can accept, the substrate utilization and degradation will decrease [11], [14]. This result is similar with previous study where they observed that substrate inhibition likely to occur at higher glucose concentration due to the alteration of metabolic pathways [11], [15]. The accumulation of volatile fatty acids (VFAs) such as ethanol or propionate in the fermenter due to high glucose concentration indicates that the fermentation process favours the ethanol pathway than acetate or butyrate pathway, and hence, reduce hydrogen production. In all experiments, $\mathrm{pH}$ was dropped from initial $\mathrm{pH}$ of 5.5 to $4.98 \pm 0.27$ after 72 hours cultivation.

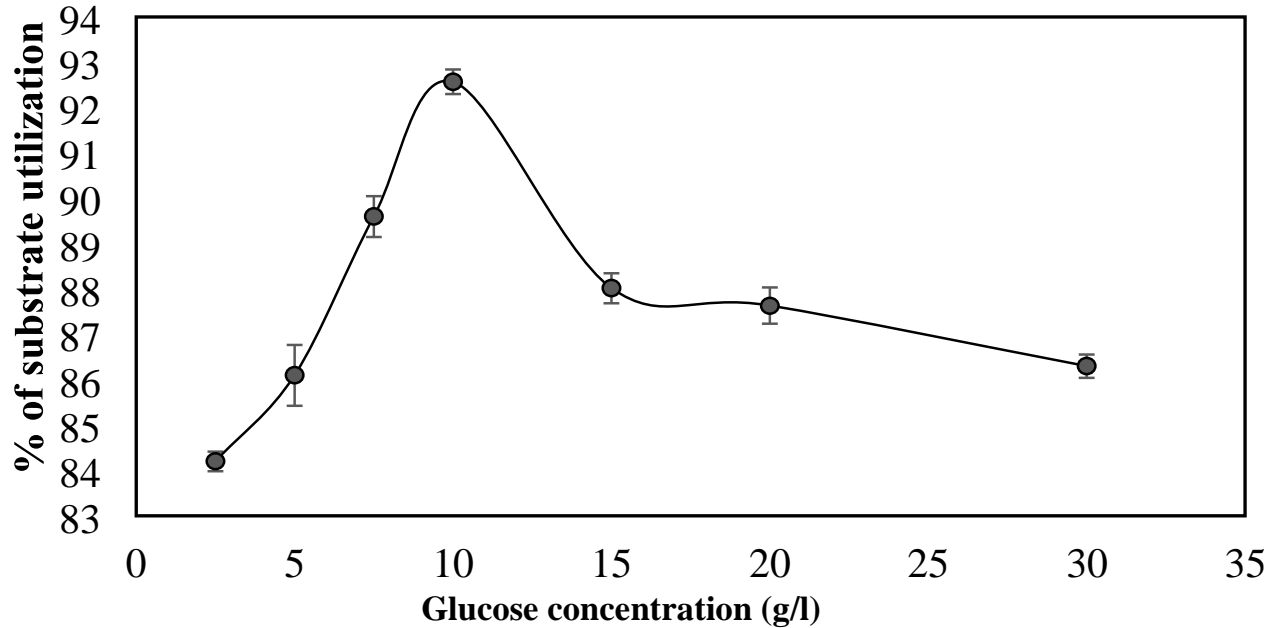

Figure 3: Substrate utilization for various concentration of glucose concentration. 


\section{International Journal of Current Science Research and Review}

ISSN: 2581-8341

Volume 05 Issue 01 January 2022

DOI: 10.47191/ijcsrr/V5-i1-03, Impact Factor: 5.825

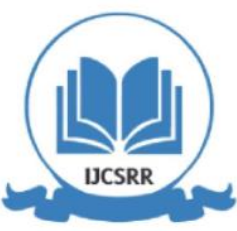

www.ijesrr.org

Substrate utilization by the bacteria to support its growth was measured using the kinetic model. Generally, there are two ways to evaluate the effect of substrate concentration during fermentation process, one is by monitoring the bacterial growth and another is by evaluating the substrate utilization to produce the fermentation product [16]. Firstly, the effect of substrate concentration on bacterial growth can be determined using the simple Monod's model (Equation 1), where the important parameters such as maximum specific growth rate $\left(\mu_{\max }\right)$ and Monod constant, $\mathrm{K}_{\mathrm{s}}$ were estimated by plotting the graph of $1 / \mu$ against $1 / \mathrm{S}$, and the slope of the straight line will give the value for $\mathrm{K}_{\mathrm{s}}$ and $\mu_{\max }$. The value of $\mathrm{K}_{\mathrm{s}}$ and $\mu_{\max }$ for each glucose concentration was represent in Table I. While Figure 4 represented the specific growth rate as a function of glucose concentration. It is found that the experimental results followed a typical shape of Monod model. As the concentration of glucose increase $(>10 \mathrm{~g} / \mathrm{l})$, the specific growth rate $(\mu)$ also increases non-linearly and reached the maximum value of $0.068 \mathrm{~h}^{-1}$. The increasing values of $\mathrm{K}_{\mathrm{s}}$ when glucose concentration increase while the maximum specific growth rate $\left(\mu_{\max }\right)$ decreases indicate that the bacterial growth was dependant with glucose concentration. This result was similar with the values of $\mu_{\max }$ in previous studies involving the mixed bacterial culture [16]-[18]. The extrapolation of the curve in Figure 4, showed that the $K_{\mathrm{s}}$ or saturation constant that equal to the concentration of the ratelimiting substrate when the maximum specific growth rate is equal to one half of the maximum, which is about $7.82 \mathrm{~g} / \mathrm{l}$. The $\mathrm{K}_{\mathrm{s}}$ value basically represents the amount of substrate concentration that had been utilized by the bacteria to achieve half ( $50 \%$ ) of the maximum substrate degradation rate or known as substrate saturation constant [19]. This value is useful to set the optimum amount of substrate concentration needed to achieve maximum production during the fermentative hydrogen production. Besides that, $\mathrm{K}_{\mathrm{s}}$ value also important in determined the efficiency of conversion of substrate to biomass [20], [21].

Table I: Effect of substrate concentration on kinetic parameter based on Monod equation

\begin{tabular}{ccccccc}
\hline $\begin{array}{c}\text { Concentration } \\
\text { of Glucose }(\mathrm{g} / \mathrm{l})\end{array}$ & $\begin{array}{c}\text { Biohydrogen } \\
\text { Produced } \\
(\mathrm{ml})\end{array}$ & $\begin{array}{c}\mathrm{K}_{\mathrm{s}} \text {, substrate } \\
\text { saturation } \\
\text { constant }(\mathrm{g} / \mathrm{l})\end{array}$ & $\begin{array}{c}\text { Specific Growth } \\
\text { Rate, } \mu\left(\mathrm{h}^{-1}\right)\end{array}$ & $\begin{array}{c}\text { Yxs } \\
(\mathrm{g} \text { cell/ } \mathrm{g} \\
\text { substrate) }\end{array}$ & $\begin{array}{c}\mathrm{Y}_{\mathrm{PS}} \\
(\mathrm{mol} \\
\text { mol substrate) }\end{array}$ & $\begin{array}{c}\mathrm{H}_{2} / \\
\mathrm{R}^{2}\end{array}$ \\
\hline 2.5 & 126 & 1.84 & 0.012 & 1.044 & 0.985 & 0.976 \\
5 & 148 & 3.51 & 0.018 & 0.916 & 1.053 & 0.929 \\
7.5 & 221 & 6.45 & 0.028 & 0.835 & 1.201 & 0.919 \\
10 & 241 & 8.10 & 0.040 & 0.398 & 1.336 & 0.972 \\
15 & 275 & 14.02 & 0.049 & 0.258 & 0.894 & 0.993 \\
20 & 259 & 17.98 & 0.062 & 0.104 & 0.578 & 0.826 \\
30 & 185 & 19.21 & 0.068 & 0.087 & 0.355 & 0.884 \\
\hline
\end{tabular}

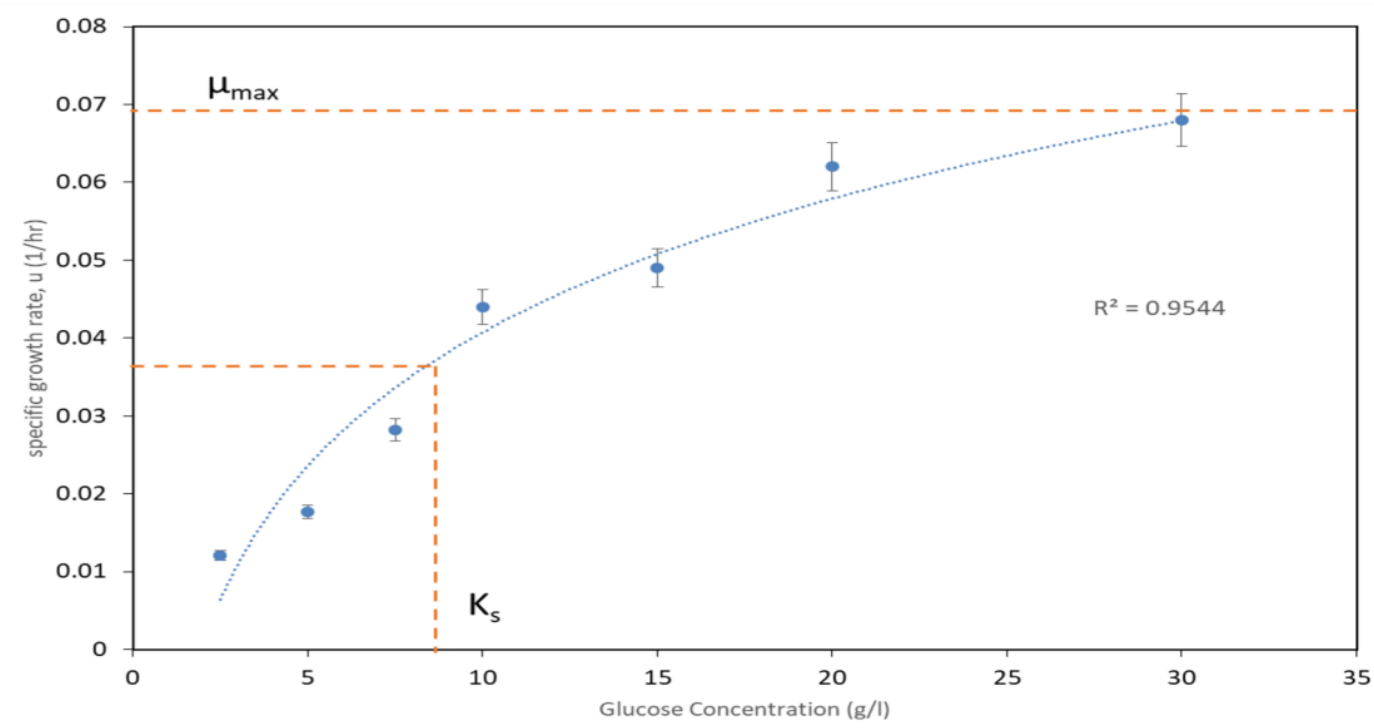

Figure 4: The kinetic analysis of bacterial growth rate $(\mu)$ at various glucose concentration. 


\section{International Journal of Current Science Research and Review}

ISSN: 2581-8341

Volume 05 Issue 01 January 2022

DOI: 10.47191/ijcsrr/V5-i1-03, Impact Factor: 5.825

IJCSRR@ 2022

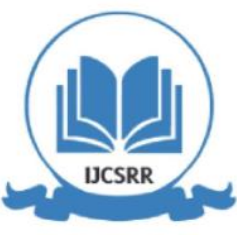

www.ijesrr.org

Variation of the hydrogen yield over the concentration of substrate can be seen in Table I. The hydrogen yield coefficient ( $\mathrm{Y}_{\mathrm{ps}}$ ) was increased as the substrate concentration increase from $2.5 \mathrm{~g} / \mathrm{l}$ to $10 \mathrm{~g} / \mathrm{l}$ before the $\mathrm{Y}_{\mathrm{ps}}$ started dropped when the substrate concentration more than $15 \mathrm{~g} / \mathrm{l}$. This trend showed that the hydrogen yield coefficient dropped sharply due to substrate inhibition at higher level. The maximum substrate utilization rate as well as hydrogen production was achieved when the substrate concentration was $10 \mathrm{~g} / \mathrm{l}$ (Figure 2 and 3 respectively).

The specific rates of sugar utilization were calculated using the Equation 4 [22], which take into account the inhibition effect of the substrate to the bacterial growth. Here, the initial biomass used in this study was, $\mathrm{X}_{0}=0.18 \mathrm{~g} / \mathrm{l}$. However, in order to determine the rate constant for sugar utilization, $\mathrm{k}$ (g substrate per $\mathrm{g}$ biomass per hours), we assumed that sugar utilization rate was occurred during the low concentration of substrate, which similar to Monod's model for bacterial growth, and thus, by re-arranged the Equation 3, resulting Equation 4 which can be used to plot the linear graph of $\left(1 / \mathrm{q}_{\mathrm{s}}\right.$ versus $\left.1 / \mathrm{S}_{\mathrm{o}}\right)$ to find the $\mathrm{K}_{\mathrm{s}}$, $\mathrm{k}$ and qm [22]. qm is $\mathrm{kX}_{0}$, the maximum rate of substrate utilization ( $\mathrm{g}$ substrate $\mathrm{l}^{-1} \mathrm{~h}^{-1}$ ).

$$
\begin{array}{ll}
q s=\frac{k X o S o}{K s+S o} \cdot \frac{K s i}{K s i+S o} & (\text { Equation 3) } \\
q s=\frac{k X o S o}{K s+S o}=\left(\frac{q m S o}{K s+S o}\right) & (\text { Equation 4) }
\end{array}
$$

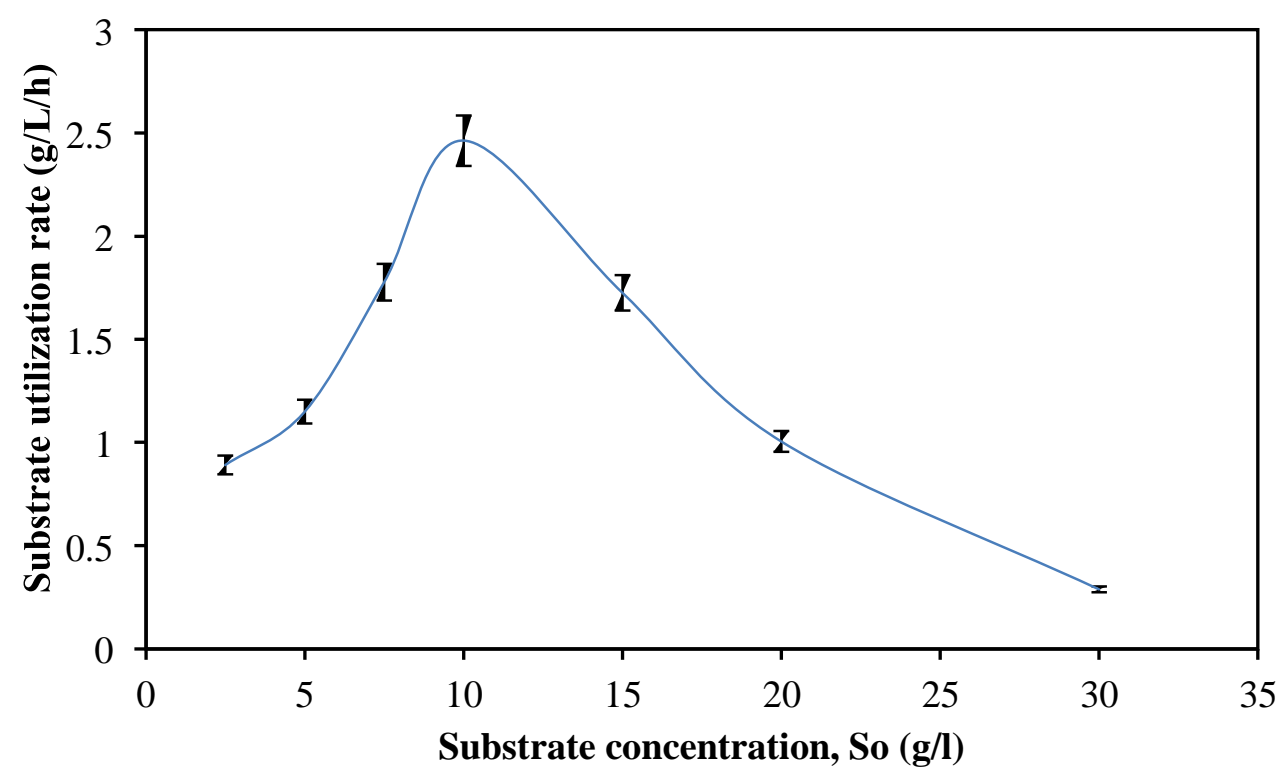

Figure5: Substrate utilization rate with various initial glucose concentrations

The plotted of substrate utilization rate was found that rate of sugar utilization dropped when the initial substrate more than 10 $\mathrm{g} / \mathrm{l}$ (Figure 5). It was found that when the experimental data (Table II) for sugar concentration below $10 \mathrm{~g} / \mathrm{l}$ was $\mathrm{plotted}$, qm $=3.67$ $\mathrm{g}$ substrate $\mathrm{l}^{-1} \mathrm{~h}^{-1}, \mathrm{~K}_{\mathrm{s}}=8.23 \mathrm{~g} / \mathrm{l}$ and $\mathrm{k}=20.37 \mathrm{~g}$ substrate $\mathrm{X}^{-1} \mathrm{~h}^{-1}$ since $\mathrm{X}_{0}=0.18 \mathrm{~g} / \mathrm{l}$. The coefficient of determination $\left(\mathrm{R}^{2}\right)$ for the fitting was greater than 0.92 , it can be concluded that this model is suitable to describe the effect of substrate concentration on bacterial growth rate for this study. Thus, Equation 5 when $\mathrm{S}_{0}<10 \mathrm{~g} / \mathrm{l}$ :

$$
q s=\frac{20.37 \times o S o}{8.23+\text { So }} \quad(\text { Equation 5) }
$$




\section{International Journal of Current Science Research and Review}

ISSN: 2581-8341

Volume 05 Issue 01 January 2022

DOI: 10.47191/ijesrr/V5-i1-03, Impact Factor: 5.825

IJCSRR@ 2022

Table II: Kinetic data for substrate utilization

\begin{tabular}{llll}
\hline \multicolumn{1}{c}{$\mathrm{S}_{\mathrm{o}}(\mathrm{g} / \mathrm{l})$} & $1 / \mathrm{S}_{\mathrm{o}}$ & $\mathrm{qS}_{\mathrm{o}}(\mathrm{g} / \mathrm{l} / \mathrm{h})$ & $1 / \mathrm{qs}_{\mathrm{o}}$ \\
\hline 2.5 & 0.4 & 0.891 & 1.122 \\
5 & 0.2 & 1.149 & 0.870 \\
7.5 & 0.1333 & 1.776 & 0.563 \\
10 & 0.1 & 2.462 & 0.406 \\
15 & 0.0667 & 1.725 & 0.580 \\
20 & 0.05 & 1.084 & 0.923 \\
30 & 0.0333 & 0.356 & 2.809 \\
\hline $\mathrm{X}_{\mathrm{o}}=0.18 \mathrm{~g} / \mathrm{l}$ & &
\end{tabular}

\section{B. Effect of adding micronutrient on bacterial growth and biohydrogen production}

Iron nanoparticles was added to the media in the range of 0 to $500 \mathrm{mg} / \mathrm{l}$, while the glucose concentration was fixed to $10 \mathrm{~g} / \mathrm{l}$. The kinetic of iron utilization was carried out with the assumption that it was needed in the reaction process due to it catalytic behaviors for stimulation of required enzymes. It is well known that the presence of iron during the hydrogen fermentation able to activate the hydrogenase enzyme, an essential enzyme for biohydrogen production [23]. Additionally, iron NPs also able to enhance bacterial flocculation/agglomeration when the $\mathrm{pH}$ of the fermentation media in the suitable range [12].

In order to estimate the suitable kinetic model for the iron NPs consumption during hydrogen fermentation, the time profiles of iron NPs consumption and cells concentration were plotted as Figure 6. It was found that as iron NPs intake decreased, the cell concentrations increased. The trend was similar for concentration of iron NPs of $25 \mathrm{mg} / \mathrm{l}$ until $200 \mathrm{mg} / \mathrm{l}$ but when the iron NPs concentration is higher than $200 \mathrm{mg} / \mathrm{l}$, more iron NPs uptake caused the cell concentration to decrease. Thus, it is showed that 500 $\mathrm{mg} / \mathrm{l}$ of iron NPs will inhibit the cells growth as well as hydrogen production (Figure 6). Furthermore, higher concentration of iron NPs will cause shifted of metabolic pathways that caused more hydrogen consumer by-product produced such as propionate acid. Generally, when the nutrient such as metal ions was in excess, bacterial will use the excess energy for cell maintenance either by increasing the cells concentration or formation of soluble metabolite product such as organic solvents like propionate or lactic acid [24].

Biomass growth kinetic for fermentative hydrogen production was analyzed using Monod equation. The specific growth rate $(\mu)$ and saturation constant (Ks) were estimated by linearized the Lineweaver-Burk equation. The values were shown in Table III for each concentration of iron NPs. The value of $\mu$ increase with the increasing of iron NPs concentration, with the minimum was 0.0375 $\mathrm{h}^{-1}$ till $0.0674 \mathrm{~h}^{-1}$ when the iron NPs concentration was $25 \mathrm{mg} / \mathrm{l}$ and $200 \mathrm{mg} / \mathrm{l}$ respectively. However, after $200 \mathrm{mg} / \mathrm{l}$, the $\mu$ value started decreasing, which is probably due to the inhibition of the bacterial growth at higher iron NPs concentration. Table III also shows that the $\mu_{\max }$ decreases with increased in iron NPs concentration. The decreasing of maximum specific growth rate probably due to reduction of $\mathrm{pH}$ since the $\mathrm{pH}$ value was not controlled throughout the experiments. The value of $\mu_{\max }$ is dependent on $\mathrm{pH}$ and temperature of the fermentation medium [25]. Similar observation also experienced by Nath and co-workers when they observed the kinetic of glucose during two-stage fermentation process [15]. It was known that $\mu_{\max }$ and Ks have significant meaning in production process as it can be used to design the process for large-scale hydrogen production. For example, from this study, it was found that the optimum amount of iron NPs for maximum hydrogen production was at $50 \mathrm{mg} / \mathrm{l}$ of iron NPs concentration, and the kinetic analysis found that $\mu_{\max }$ for this optimum iron NPs concentration was at $0.0032 \mathrm{~h}^{-1}$, thus indicate that for continuous system, the suitable dilution rates should not exceed this value. While Ks value for optimum iron NPs concentration ( $35.05 \mathrm{mg} / \mathrm{l}) \mathrm{represents}$ the iron NPs concentration needed to achieve the maximum growth rate for the bacteria, which indicates that the value is the most efficient iron NPs concentration in the influent [26]. 
International Journal of Current Science Research and Review

ISSN: 2581-8341

Volume 05 Issue 01 January 2022

DOI: 10.47191/ijcsrr/V5-i1-03, Impact Factor: 5.825

IJCSRR@ 2022

www.ijjcsrr.org
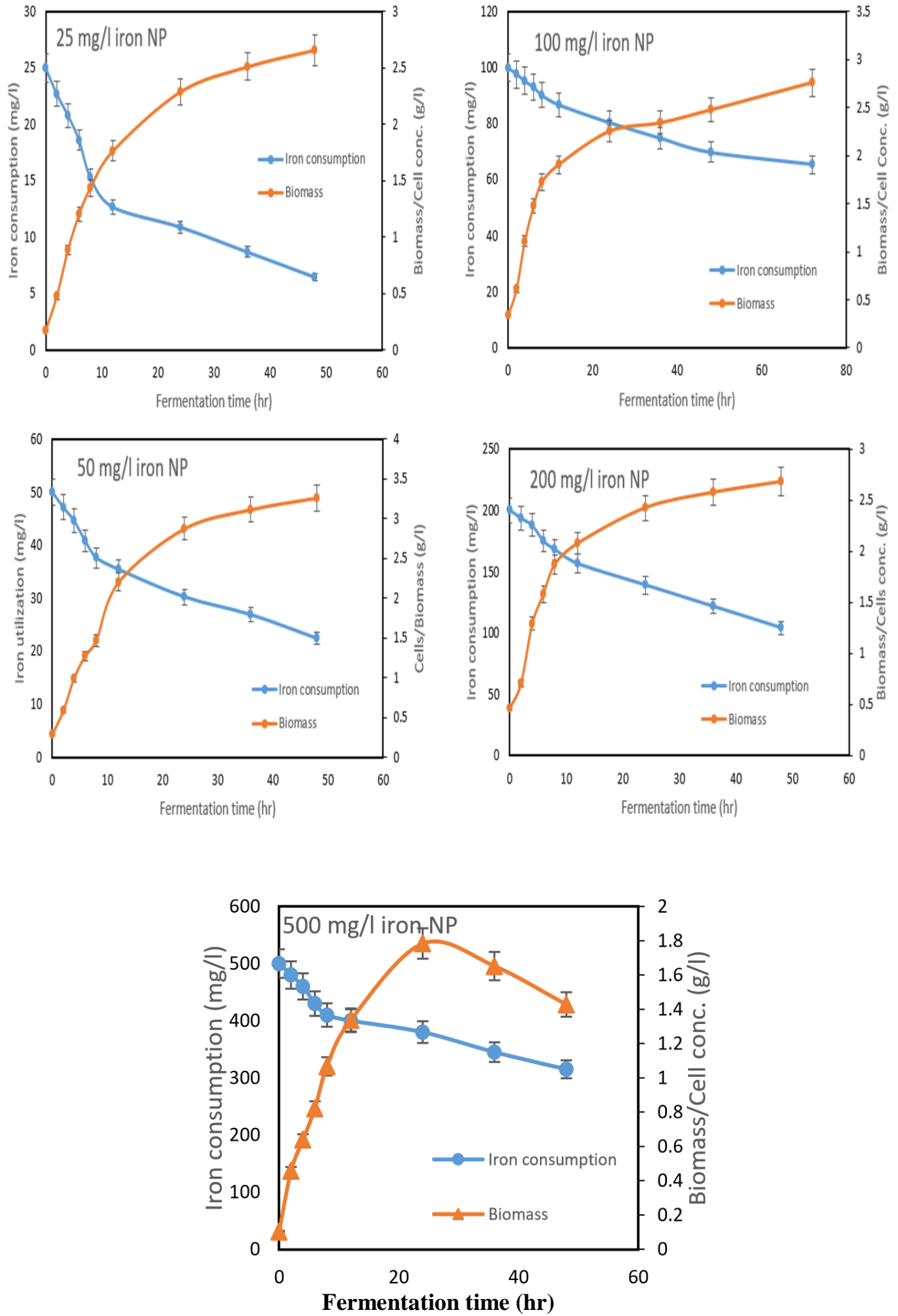

Figure 6: Time profile for iron consumption and cell concentrations at various iron NPs concentration (mg/l). 


\section{International Journal of Current Science Research and Review}

ISSN: 2581-8341

Volume 05 Issue 01 January 2022

DOI: 10.47191/ijesrr/V5-i1-03, Impact Factor: 5.825

IJCSRR@ 2022

Www.ijesrr.org

Table III: Kinetic parameter and distribution of soluble metabolite at various iron NPs concentration (mg/l)

\begin{tabular}{cccccccccc}
\hline $\begin{array}{c}\text { Conc. of } \\
\text { Iron NPs } \\
(\mathrm{mg} / \mathrm{l})\end{array}$ & $\begin{array}{c}\mathrm{HPR} \\
(\mathrm{L} / \mathrm{L} / \mathrm{d})\end{array}$ & $\begin{array}{c}\text { Yield }\left(\mathrm{mol} \mathrm{H}_{2} /\right. \\
\text { mol glucose })\end{array}$ & $\mu\left(\mathrm{h}^{-1}\right)$ & $\mathrm{K}_{\mathrm{s}}(\mathrm{mg} / \mathrm{l})$ & $\begin{array}{c}\text { Yxs } \\
(\mathrm{g} \text { cell/g } \\
\text { iron })\end{array}$ & $\begin{array}{c}\text { Substrate } \\
\text { Consumption } \\
(\%)\end{array}$ & $\begin{array}{c}\mathrm{Hac} \\
(\mathrm{mM})\end{array}$ & $\begin{array}{c}\mathrm{HBu} \\
(\mathrm{mM})\end{array}$ & $\begin{array}{c}\mathrm{HPr} \\
(\mathrm{mM})\end{array}$ \\
\hline 25 & 0.678 & $1.09 \pm 0.21$ & 0.0375 & 15.26 & 0.143 & $88 \pm 0.2$ & $27 \pm 1.6$ & $15 \pm 1.2$ & $13 \pm 1.6$ \\
50 & 0.828 & $1.40 \pm 0.47$ & 0.0480 & 35.05 & 0.121 & $89 \pm 0.9$ & $32 \pm 2.5$ & $17 \pm 2.2$ & $11 \pm 0.9$ \\
100 & 0.573 & $0.94 \pm 0.32$ & 0.0571 & 93.96 & 0.088 & $87 \pm 0.7$ & $25 \pm 2.0$ & $23 \pm 0.8$ & $18 \pm 2.1$ \\
200 & 0.548 & $0.93 \pm 0.18$ & 0.0674 & 177.72 & 0.032 & $86 \pm 0.4$ & $20 \pm 2.4$ & $21 \pm 0.9$ & $25 \pm 1.1$ \\
500 & 0.537 & $0.82 \pm 0.33$ & 0.0239 & 416.73 & 0.016 & $84 \pm 0.8$ & $16 \pm 3.5$ & $22 \pm 0.4$ & $31 \pm 0.3$ \\
\hline
\end{tabular}

\section{Kinetic analysis of substrate and micronutrients inhibition on biohydrogen production}

High dosage of substrate concentration or trace element will cause the inhibition effect to the bacterial growth as well as the product formation. Since Monod's equation only applicable when substrate concentration is low, and the bacterial growth is slow. However, when dealing with high substrate concentration and rapid growth of bacteria, Andrew's equation (Equation 6) is most suitable to explain the inhibition process due to high dosage of substrate or the existence of toxic material, where, $\mathrm{q}_{\mathrm{s}}$ is the specific substrate utilization rate $(1 / \mathrm{X} * \mathrm{dS} / \mathrm{dt})$.

$$
\mu=\mathrm{Y}_{\mathrm{X} / \mathrm{S}} / \mathrm{X} *(\mathrm{dS} / \mathrm{dt})=\mathrm{Y}_{\mathrm{x} / \mathrm{s}} * \mathrm{q}_{\mathrm{s}} \quad \text { (Equation 6) }
$$

Kinetic inhibition model was proposed earlier by Andrews (Equation 6) [5]. At high substrate concentration, for this study, when glucose concentration above $10 \mathrm{~g} / \mathrm{l}(>1 \mathrm{~g} / \mathrm{l})$, the inhibition effect can be observed as presented in Figure 5. This time, the Andrew's model was modified to Equation 7 in order to determine the rate constant for sugar utilization, $\mathrm{k}$ ( $\mathrm{g}$ substrate per $\mathrm{g}$ biomass per hours), we assumed that sugar utilization rate was occurred during the low concentration of substrate, which similar to Monod's model for bacterial growth, and thus, by re-arranged the Equation 7, resulting Equation 8 which can be used to plot the linear graph of $\left(1 / \mathrm{q}_{\mathrm{s}}\right.$ versus $\left.1 / \mathrm{S}_{\mathrm{o}}\right)$ to find the $\mathrm{K}_{\mathrm{s}}$, $\mathrm{k}$ and $\mathrm{qm}[22]$. qm is $\mathrm{kX}_{0}$, the maximum rate of substrate utilization $\left(\mathrm{g}\right.$ substrate $\left.\mathrm{l}^{-1} \mathrm{~h}^{-1}\right)$.

$$
\begin{array}{ll}
q s=\frac{k X o S o}{K s+S o} \cdot \frac{K s i}{K s i+S o} & (\text { Equation 7) } \\
q s=\frac{k X o S o}{K s+S o}=\left(\frac{q m S o}{K s+S o}\right) & (\text { Equation 8) }
\end{array}
$$

However, only inhibition term was considered as below:

$$
q s=q m \frac{K s i}{K s i+S o}=k^{\prime} X o \frac{K s i}{K s i+S o} \quad \text { (Equation 9) }
$$

Linearize the Equation 10, will result the Equation 11, which will use to plot the experimental data from Table II (plot of 1/q $\mathrm{q}_{\mathrm{s}}$ versus $\mathrm{S}_{\mathrm{o}}$ ) to determine the following constant: $\mathrm{qm}=0.628 \mathrm{~g}$ substrate $\mathrm{l}^{-1} \mathrm{~h}^{-1}, K_{s i}=10.11 \mathrm{~g} / \mathrm{l}$ and $k^{\prime}=3.49 \mathrm{~g}^{\prime}$ substrate $\mathrm{X}^{-1} \mathrm{~h}^{-1}$ when $\mathrm{Xo}^{\prime}=$ $0.18 \mathrm{~g} / \mathrm{l}$. The final model of substrate inhibition according to Equation 9 is Equation 11:

$$
\begin{array}{ll}
\frac{1}{q s}=\frac{1}{q m}+\frac{S o}{q m K s i} & (\text { Equation 10) } \\
q s=k^{\prime} X o \frac{K s i}{K s i+S o}=3.49 \times o \frac{10.11}{10.11+S o} & \text { (Equation 11) }
\end{array}
$$

The result showed that there was a presence of substrate inhibition, as from Figure 5, there was increasing in substrate utilization rate initially, before it had been declined as the substrate concentration increased. In this case, we assumed that this inhibition was based on competitive effect, where the inhibition was caused by the substrate itself [23], in which $S>>K_{s}$. In the meantime, it is found that $\mathrm{K}_{\mathrm{s}}$ and $\mathrm{Y}_{\mathrm{xs}}$ value (Table I) were inversely proportional to each other with increasing of substrate concentration. The $\mathrm{K}_{\mathrm{s}}$ value reflects the bacterial affinity for its substrate, in which at higher $\mathrm{K}_{\mathrm{s}}$ value will influence the substrate concentration to affect the bacterial growth and hence, decreased the $\mu_{\max }$ when substrate concentration was increased [24].

Since $K_{s i} \gg K_{s}$, thus showed that when substrate concentration equal to $K_{s i}$, then, the increasing concentration of substrate will be inhibitor for the system. Inhibition could be in term of slowing down the reaction or killing the active bacteria inside the system. However, in this study, it was found that the substrate inhibition caused the production of hydrogen consumers, which can be detected by the presence of propionate acid (Table IV). The similar observation was reported by Nath and co-workers where they found that during the glucose inhibition, at concentration greater than $15 \mathrm{~g} / \mathrm{l}$ propionate acid and ethanol was accumulated and 


\section{International Journal of Current Science Research and Review}

ISSN: 2581-8341

Volume 05 Issue 01 January 2022

DOI: 10.47191/ijcsrr/V5-i1-03, Impact Factor: 5.825

IJCSRR@ 2022

www.ijcsrr.org

dropped the hydrogen production. Accumulation of this acid reduced the production yield and productivity [15]. Thus, it is better to keep the concentration of substrate in optimum amount to reduce or avoid the inhibition effect.

Table IV: Kinetic parameter and distribution of soluble metabolite at various substrate concentration $(\mathrm{g} / \mathrm{l})$

\begin{tabular}{ccccccc}
\hline $\begin{array}{c}\text { Conc. of } \\
\text { Glucose }(\mathrm{g} / \mathrm{l})\end{array}$ & HPR $(\mathrm{L} / \mathrm{L} / \mathrm{d})$ & $\begin{array}{c}\text { Yield }(\mathrm{mol} \mathrm{H} / \\
\text { mol glucose })\end{array}$ & $\begin{array}{c}\text { Substrate } \\
\text { Consumption }(\%)\end{array}$ & $\begin{array}{c}\text { HAc } \\
(\mathrm{mM})\end{array}$ & $\begin{array}{c}\mathrm{HBu} \\
(\mathrm{mM})\end{array}$ & $\begin{array}{c}\mathrm{HPr} \\
(\mathrm{mM})\end{array}$ \\
\hline 2.5 & 0.295 & $2.05 \pm 0.42$ & $84 \pm 0.5$ & $22 \pm 1.6$ & $20 \pm 0.8$ & $13 \pm 1.1$ \\
5 & 0.375 & $1.28 \pm 0.28$ & $86 \pm 0.3$ & $25 \pm 2.5$ & $16 \pm 0.5$ & $11 \pm 0.7$ \\
7.5 & 0.565 & $1.23 \pm 0.53$ & $90 \pm 0.7$ & $27 \pm 2.0$ & $27 \pm 0.8$ & $18 \pm 1.5$ \\
10 & 0.608 & $0.98 \pm 0.22$ & $93 \pm 0.3$ & $32 \pm 2.4$ & $23 \pm 0.7$ & $16 \pm 0.1$ \\
15 & 0.695 & $0.75 \pm 0.57$ & $88 \pm 0.8$ & $25 \pm 3.5$ & $24 \pm 0.4$ & $21 \pm 1.3$ \\
20 & 0.648 & $0.52 \pm 0.62$ & $87 \pm 0.6$ & $20 \pm 4.1$ & $23 \pm 0.3$ & $25 \pm 0.6$ \\
30 & 0.545 & $0.31 \pm 0.49$ & $86 \pm 0.4$ & $18 \pm 2.3$ & $21 \pm 0.5$ & $32 \pm 0.7$ \\
\hline
\end{tabular}

As we can see that the substrate concentration above $10 \mathrm{~g} / \mathrm{l}$ will cause the inhibition to the system, then, investigation on the inhibition effect of the addition of iron NPs were done by using fixed amount of substrate (10 g/l) while varying the concentration of NPs (mg/l). Similarly, the plot of specific growth rate, $\mu$ against concentration of iron NPs was used to evaluate the concentration of NPs that might become the inhibitor to the system (Figure 7). It showed that the concentration higher than $200 \mathrm{mg} / \mathrm{l}$ will drop the $\mu$ value.

By using the same equation (Equation 10), the effect of adding iron NPs on bacterial growth was measured using the experimental values from Table $\mathrm{V}$. The plot of $1 / \mu$ against $\mathrm{S}_{\mathrm{i}}$ (concentration of iron NPs), found that $\mu_{\max }=0.0392 \mathrm{mg} \mathrm{NPs} / \mathrm{l} / \mathrm{hr}, \mathrm{K}_{\mathrm{si}}=432.72 \mathrm{mg} / \mathrm{l}$ and $\mathrm{k}^{\prime}$ when $\mathrm{Xo}=0.18 \mathrm{~g} / \mathrm{l}=0.22 \mathrm{mg} \mathrm{NPs} \mathrm{g}^{-1} \mathrm{X} \mathrm{hr}^{-1}$. While if the plot of $1 / \mu$ against $1 / \mathrm{S}_{\mathrm{i}}$ by considering the utilization of iron NPs, $\mu \mathrm{m}=0.072 \mathrm{mg} \mathrm{NPs} / \mathrm{l} / \mathrm{hr}, \mathrm{K}_{\mathrm{s}}=23.71 \mathrm{mg} / \mathrm{l}$ and $\mathrm{k}=0.4 \mathrm{mg} \mathrm{NPs} \mathrm{g}^{-1} \mathrm{X} \mathrm{hr}^{-1}$. Thus, the result showed that inhibition effect will take place when iron NPs was supplied more than $200 \mathrm{mg} / \mathrm{l}$ and caused inhibition to the bacterial cells. Excess amount of trace elements such as iron will disturb the metabolic activity of the enzyme inside the bacteria, and hence, decreased its productivity to produce the required product [25].

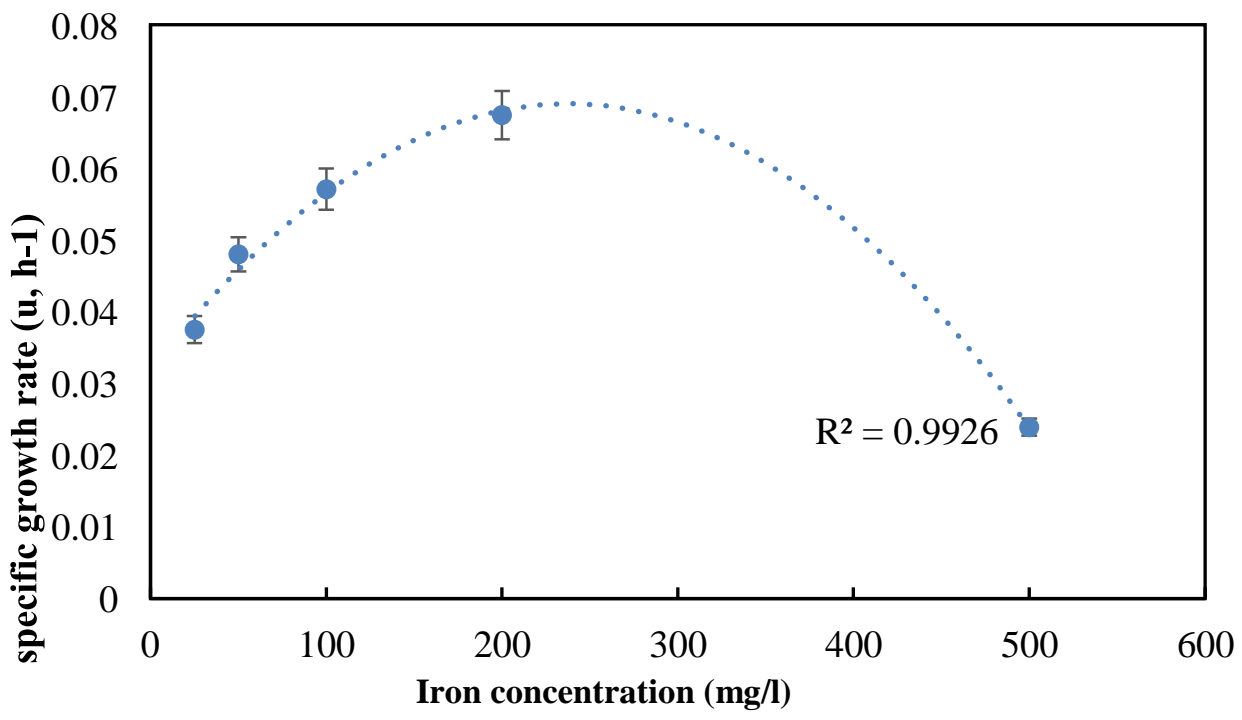

Figure 7: The kinetic analysis of bacterial growth rate $(\mu)$ at various iron NPs concentration 


\section{International Journal of Current Science Research and Review}

ISSN: 2581-8341

Volume 05 Issue 01 January 2022

DOI: 10.47191/ijesrr/V5-i1-03, Impact Factor: 5.825

IJCSRR@ 2022

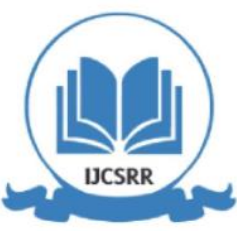

www.ijesrr.org

Table V: The experimental data and calculated kinetic values for various iron NPs concentration

\begin{tabular}{clcl}
\hline Conc. of Iron NPs $(\mathrm{mg} / \mathrm{l})$ & $\mu\left(\mathrm{h}^{-1}\right)$ & $\mu \max$ & $\mathrm{Ks}$ \\
\hline 25 & 0.038 & 0.0018 & 14.77 \\
50 & 0.048 & 0.0020 & 49.56 \\
100 & 0.057 & 0.0021 & 89.74 \\
200 & 0.067 & 0.0024 & 181.89 \\
500 & 0.024 & 0.0020 & 450.15 \\
\hline
\end{tabular}

Table $\mathrm{V}$ also showed that iron NPs acted as a competitive to the substrate during the fermentation as the iron NPs concentration increased up to $500 \mathrm{mg} / \mathrm{l}$, the maximum rate of reaction, $\mu_{\max }$ remained unchanged but the $\mathrm{K}_{\mathrm{s}}$ values were increased. Here, iron NPs competed with the substrate to bind with the enzyme during the metabolism reaction. However, in competitive inhibition, iron NPs will bind at any site on the enzyme not only on the active site. Additionally, competitive inhibitor is a type of reversible inhibition, which using the right or optimum concentration that only needed by the system could reduce the effect of inhibitor [26]. The other way to eliminate the effect of competitive inhibitor is by increasing the substrate concentration, which theoretically, increase in substrate availability will increase the chance for the substrate to bind to the enzyme but not inhibitor.

\section{CONCLUSION}

In conclusion, substrate and iron NPs concentration do affect the performance of the biohydrogen production in a way that the right concentration able to increase the hydrogen production while excess amount inhibits the reaction. Since all experiments were run using the optimum condition such as the fixed $\mathrm{pH}$ and temperature ( $\mathrm{pH} 5.5$, temperature $=55{ }^{\circ} \mathrm{C}$ ), it is better to observed the inhibition effect of substrate concentration as well as iron NPs when changing the fermentation condition as the results might be different with the finding from this study. It was found that increasing the substrate concentration more than $10 \mathrm{~g} / \mathrm{l}$ will cause the inhibition to the system, in which it will slow down the reaction process and reduced the production of hydrogen. While the presence of iron NPs more than its optimum value $(200 \mathrm{mg} / \mathrm{l})$ will inhibit the bacterial growth and hence, affect the hydrogen production. For both cases, when the inhibition occurred at the respective concentration, it was found that the metabolic pathway was shifted to produce more hydrogen-consuming metabolite such as propionate acid, and thus, dropped the hydrogen production.

\section{ACKNOWLEDGEMENT}

The author would like to thank the Ministry of Higher Education Malaysia for granted the fund for this research under the Fundamental Research Grant Scheme, FRGS/1/2019/TK07/UIAM/02/1 (FRGS19-105-0714) and to International Islamic University specifically to Department of Biotechnology Engineering for research facilities.

\section{REFERENCES}

1. D. B. Levin, L. Pitt, and M. Love, "Biohydrogen production : prospects and limitations to practical application," vol. 29, pp. 173-185, 2004, doi: 10.1016/S0360-3199(03)00094-6.

2. S. Van Ginkel, S. Sung, and J. Lay, "Biohydrogen Production as a Function of pH and Substrate Concentration," vol. 35, no. 24, pp. 4726-4730, 2001.

3. A. A. I. Luthfi, J. M. Jahim, S. Harun, J. P. Tan, S. F. A. Manaf, and S. S. M. Shah, "Kinetics of the bioproduction of succinic acid by actinobacillus succinogenes from oil palm lignocellulosic hydrolysate in a bioreactor," BioResources, vol. 13, no. 4, pp. 8279-8294, 2018, doi: 10.15376/biores.13.4.8279-8294.

4. A. L. Koch, "The Monod Model and Its Alternatives," Math. Model. Microb. Ecol., no. 2, pp. 62-93, 1998, doi: 10.1007/978-1-46154078-6_4.

5. J. F. Andrews, "A mathematical model for the continuous culture of microorganisms utilizing inhibitory substrates," Biotechnol. Bioeng., vol. 10, no. 6, pp. 707-723, 1968, doi: 10.1002/bit.260100602.

6. V. Niel, E. W. J. Van Niel, P. A. M. Claassen, and A. J. M. Stams, "Substrate and Product Inhibition of Hydrogen Production by the Extreme Thermophile, Caldicellulosiruptor saccharolyticus," 2003, doi: 10.1002/bit.10463. 


\section{International Journal of Current Science Research and Review}

ISSN: 2581-8341

Volume 05 Issue 01 January 2022

DOI: 10.47191/ijesrr/V5-i1-03, Impact Factor: 5.825

IJCSRR@ 2022

Www.ijjcsrr.org

7. S. N. Malik, V. Pugalenthi, A. N. Vaidya, P. C. Ghosh, and S. N. Mudliar, "Kinetics of nano-catalysed dark fermentative hydrogen production from distillery wastewater," Energy Procedia, vol. 54, pp. 417-430, 2014, doi: 10.1016/j.egypro.2014.07.284

8. K. Reddy et al., "Biohydrogen production from sugarcane bagasse hydrolysate: effects of $\mathrm{pH}, \mathrm{S} / \mathrm{X}, \mathrm{Fe} 2+$, and magnetite nanoparticles," Environ. Sci. Pollut. Res., vol. 24, no. 9, pp. 8790-8804, 2017, doi: 10.1007/s11356-017-8560-1.

9. I. Ntaikou, H. N. Gavala, M. Kornaros, and G. Lyberatos, "Hydrogen production from sugars and sweet sorghum biomass using Ruminococcus albus,” vol. 33, pp. 1153-1163, 2008, doi: 10.1016/j.ijhydene.2007.10.053.

10. K. Han and O. Levenspiel, "Extended Monod Kinetics for Substrate Product, and Cell Inhibition," in Biotechnology and Bioengineering, 32nd ed., Oregon: John Wiley \& Sons, Inc., 1987, pp. 430-437.

11. J. Wang and W. Wan, "Factors influencing fermentative hydrogen production: A review," Int. J. Hydrogen Energy, vol. 34, no. 2, pp. 799-811, 2009, doi: 10.1016/j.ijhydene.2008.11.015.

12. N. S. Engliman, P. M. Abdul, and S. Wu, "Influence of iron (II) oxide nanoparticle on biohydrogen production in thermophilic mixed fermentation," Int. J. of h ydrogen e nergy xxx 1e12, no. Ii, pp. 1-12, 2017.

13. S. Wu, C. Lin, J. Chang, and J. Chang, "Biohydrogen production with anaerobic sludge immobilized by ethylene-vinyl acetate copolymer," vol. 30, pp. 1375-1381, 2005, doi: 10.1016/j.ijhydene.2004.09.011.

14. Y. Akutsu, Y. Li, H. Harada, and H. Yu, "Effects of temperature and substrate concentration on biological hydrogen production from starch,” Int. J. Hydrogen Energy, vol. 34, no. 6, pp. 2558-2566, 2009, doi: 10.1016/j.ijhydene.2009.01.048.

15. K. Nath, M. Muthukumar, A. Kumar, and D. Das, "Kinetics of two-stage fermentation process for the production of hydrogen," Int. J. Hydrogen Energy, vol. 33, no. 4, pp. 1195-1203, 2008, doi: 10.1016/j.ijhydene.2007.12.011.

16. J. Wang and W. Wan, "Kinetic models for fermentative hydrogen production: A review," Int. J. Hydrogen Energy, vol. 34, no. 8, pp. 3313-3323, 2009, doi: 10.1016/j.ijhydene.2009.02.031.

17. Y. C. Lo, W. M. Chen, C. H. Hung, S. Der Chen, and J. S. Chang, "Dark H2 fermentation from sucrose and xylose using H2-producing indigenous bacteria: Feasibility and kinetic studies,” Water Res., vol. 42, no. 4-5, pp. 827-842, 2008, doi:

18. 10.1016/j.watres.2007.08.023.

19. A. Gadhe, S. S. Sonawane, and M. N. Varma, "Kinetic analysis of biohydrogen production from complex dairy wastewater under optimized condition," Int. J. Hydrogen Energy, vol. 39, no. 3, pp. 1306-1314, 2014, doi: 10.1016/j.ijhydene.2013.11.022.

20. Y. Mu, G. Wang, and H. Q. Yu, "Kinetic modeling of batch hydrogen production process by mixed anaerobic cultures," Bioresour. Technol., vol. 97, no. 11, pp. 1302-1307, 2006, doi: 10.1016/j.biortech.2005.05.014.

21. P. Harrison, J. Parslow, and H. Conway, "Determination of nutrient uptake kinetic parameters: a comparison of methods," Mar. Ecol. Prog. Ser., vol. 52, no. 3, pp. 301-312, 1989, doi: 10.3354/meps052301.

22. J. D. Owens and J. D. Legan, "Determination of the Monod substrate saturation constant for microbial growth," vol. 46, pp. 419-432, 1987.

23. S. Ozmihci and F. Kargi, "Kinetics of batch ethanol fermentation of cheese-whey powder (CWP) solution as function of substrate and yeast concentrations," Bioresour. Technol., vol. 98, no. 16, pp. 2978-2984, 2007, doi: 10.1016/j.biortech.2006.10.005.

24. J. b. s. Haldane, "Enzymes," no. 2, 1930.

25. D. Frascari et al., "A kinetic study of biohydrogen production from glucose, molasses and cheese whey by suspended and attached cells of Thermotoga neapolitana," Bioresour. Technol., vol. 147, no. February 2018, pp. 553-561, 2013, doi: 10.1016/j.biortech.2013.08.047.

26. H. Han, M. Cui, L. Wei, H. Yang, and J. Shen, "Enhancement effect of hematite nanoparticles on fermentative hydrogen production,” Bioresour. Technol., vol. 102, no. 17, pp. 7903-7909, 2011, doi: 10.1016/j.biortech.2011.05.089.

27. J. M. Berg, J. L. 1948-2019. Tymoczko, L. Stryer, and N. C. for B. I. (U. S. . T. A.-T. T. -, "Biochemistry.” W.H. Freeman ;, New York, 2002, [Online]. Available: http://catalog.hathitrust.org/api/volumes/oclc/48055706.html. 


\section{International Journal of Current Science Research and Review}

ISSN: 2581-8341

Volume 05 Issue 01 January 2022

DOI: 10.47191/ijcsrr/V5-i1-03, Impact Factor: 5.825

IJCSRR@ 2022

\section{APPENDICES}

Table VI: Raw data for initial substrate concentration used for kinetic study

\begin{tabular}{clcccccc}
\hline \multicolumn{7}{c}{ Cumulative H2 produce for different sugar concentration } \\
\hline Time (hr) & \multicolumn{7}{c}{ Glucose $(\mathrm{g} / \mathrm{l})$} \\
\hline & 2.5 & 5 & 7.5 & 10 & 15 & 20 & 30 \\
\hline 0 & 0 & 0 & 0 & 0 & 0 & 0 & 0 \\
2 & 5.44 & 8.7495 & 24.066 & 20.9312 & 21.91345 & 22.36572 & 15 \\
4 & 10.239 & 15.1725 & 34.38 & 43.944 & 44.27336 & 42.08616 & 38 \\
6 & 15.36 & 31.807 & 70.52 & 83.632 & 66.9704 & 60.83886 & 52 \\
8 & 28.14 & 67.142 & 107.85 & 118.696 & 95.39865 & 100.422 & 83 \\
12 & 40.39 & 96.653 & 149.883 & 170.896 & 167.152 & 156.9899 & 120 \\
24 & 82.67 & 138.11 & 201.42 & 229.568 & 238.3372 & 240.8616 & 155 \\
36 & 118.24 & 150.226 & 225.602 & 243.072 & 276.8224 & 258.066 & 200 \\
48 & 118.24 & 150.226 & 225.602 & 243.072 & 276.8224 & 258.066 & 218 \\
\hline
\end{tabular}

Table VII: Raw data for initial micronutrient concentration used for kinetic study

\begin{tabular}{ccccccc}
\hline \multicolumn{7}{c}{ Cells, X (mg/l) } \\
\hline Time (hr) & \multicolumn{7}{c}{ Iron NPs (mg/l) } \\
\hline 0 & 0 & 25 & 50 & 100 & 200 & 500 \\
2 & 15.80 & 17.78 & 18.4 & 17.1 & 17.4 & 15.55 \\
4 & 16.41 & 18.46 & 19.87 & 17.78 & 18.09 & 16.17 \\
6 & 17.02 & 19.15 & 20.60 & 19.15 & 19.46 & 16.79 \\
8 & 17.63 & 19.83 & 21.34 & 19.83 & 20.18 & 17.41 \\
12 & 18.84 & 21.20 & 22.81 & 21.20 & 21.57 & 19.28 \\
24 & 22.49 & 25.30 & 27.23 & 25.30 & 25.75 & 23.01 \\
36 & 26.144 & 29.412 & 31.648 & 29.412 & 29.928 & 26.74 \\
48 & 29.792 & 33.516 & 36.064 & 33.516 & 34.104 & 30.478 \\
72 & & & 41.724 & &
\end{tabular}

Cite this Article: Nurul Sakinah Engliman, Ainul Husna Abdul Aziz, Mariatul Fadzillah Mansor, Peer Mohamed Abdul, Jamaliah Md Jahim, Nur Syakina Jamali (2022). Kinetic Study on the Effect of Substrate and Micronutrient Inhibition during Anaerobic Fermentation of Biohydrogen. International Journal of Current Science Research and Review, 5(1), 13-25 